\title{
AGRICULTURAL BUDGET AND AGRICULTURE DEVELOPMENT IN REPUBLIC OF SERBIA
}

\author{
Boris Kuzman ${ }^{1}$, Katarina Djuric ${ }^{2}$, Ljubomir Mitrovic ${ }^{3}$, Radivoj Prodanovic ${ }^{4}$
}

\begin{abstract}
Considering that agriculture is significant activity in the Republic of Serbia, the country pursues the politics of encouraging it through the agricultural budget in order to develop and bring greater effects. The aim of paper is to depict the state of agriculture in the Republic of Serbia and agricultural budget, as an instrument of agricultural politics in function of agricultural sector development. Tendency is to explore whether the amount and structure of agricultural budget is adequate to objectives of the Strategy for agriculture development of the Republic of Serbia. By application of historical and descriptive method, the impact of agricultural budget to the agriculture development in the Republic of Serbia is reviewed. On the other hand, comparative analysis of statistical data provided the adoption of conclusions on the structure and amount of agricultural budget for the future. Graphical methods, indicators, logical methods and other standard methods are also used. For the more dynamic agriculture development of the Republic of Serbia, the resources of agricultural budget are not sufficient. The reform of agricultural policy is necessary, where the agricultural budget will gain in significance. The most effective is to direct the resources to new investments, infrastructural projects in rural areas, to stimulate intensive and export-oriented production, processing, as well as systems of sustainable agriculture.
\end{abstract}

Key words: agricultural budget, agricultural policy, agriculture, rural development, Republic of Serbia.

JEL: 013, Q14, Q18

1 Boris Kuzman Ph.D., Associate Professor, Institute of Agricultural Economics, Volgina Street no. 15, 11060 Belgrade, Serbia, Phone: +381 63299 111, E-mail: kuzmanboris@yahoo.com

2 Katarina Djuric Ph.D., Associate Professor, Faculty of Agriculture, Dositeja Obradovica Square no. 8, 21000 Novi Sad, Phone: + 3812148532 32, E-mail: katarina.djuric@polj.uns.ac.rs

3 Ljubomir Mitrović Ph.D., Full Professor, University in Pristina, Faculty of Law, Lole Ribara Street no. 29, 38220 Kosovska Mitrovica, Phone: +381 28425 339, E-mail: slavka.mitrovic@pr.ac.rs

4 Radivoj Prodanovic Ph.D., Assistant Professor, University Business Academy in Novi Sad, Faculty of Economics and Engineering Management in Novi Sad, Cvecarska Street no. 2, 21000 Novi Sad, Serbia, Phone: +381 21400 484, E-mail: rprodanovic@fimek.edu.rs

EP 2017 (64) 2 (515-531) 


\section{Introduction}

Agriculture in the Republic of Serbia has economic, social and political importance. Given that agriculture has significant share in making the total gross domestic product (GDP), to employ huge number of people, the question of the possibility of its further development is logically imposed.

The interest of the state for co-financing agriculture is reflected in the fact that it is significant for national economy (contribution to GDP, employment, natural resources), and especially as each country tends to ensure food security.

The main aim of agricultural policy is to enhance the quality and quantity of agricultural and food products, the stabilization and growth of the food market, providing the supply the consumers at reasonable prices, as well as providing higher living standard of farmers. To accomplish those aims, it is necessary to determine funding through agricultural budget.

Co-financing of agriculture through agricultural budget is complex, and the essence of problem is the inadequate relation between the allocations from the state budget and the contribution of agriculture to the making added gross value. Contribution of agriculture to national economy is significantly higher relative to the allocations from the agricultural budget.

The EU agricultural policy is the framework of common action and substantial part of the funds is allocated for improving the financial situation of farmers, enhancing the production of quality food products, stabilization of food market and others. Given that the Republic of Serbia tends to integrate into the EU, its measures of agricultural policy should be the leading idea in creation of national agricultural policy and agricultural budget.

\section{Aim and Significance of Paper}

The aim of paper is to represent mechanisms for budget support for primary agricultural production in the Republic of Serbia, and tend to quantify their contribution to the growth and development of this strategic activity. It is tended to explore how the amount and structure of agricultural budget affect the agriculture development.

Since that agriculture in the Republic of Serbia is strategically important economic activity, the research, which is aimed to overview the possibilities of its further development, can be considered as significant.

\section{Methodology and Data Sources}

Quantitative qualitative methods are applied in paper. By application of historical and descriptive method, the impact of agricultural budget on development of agricultural production in the Republic of Serbia is reviewed. On the other hand, comparative analysis of statistical data provided the adoption of conclusions of structure and amount of agricultural budget for future. Graphical method, indicators, logical method and other standard methods are used.

Scientific papers, publications of the republic Institute for Statistics, professional websites 
are used for actualizing the insight in structure and distribution of funds, which are opted for through the agricultural budget.

\section{Agriculture in the Republic of Serbia}

Agriculture and rural areas take significant place in the Development strategy of the Republic of Serbia. Agriculture of the Republic of Serbia is characterized by huge number of small households with distracted property, which is negatively reflected to its competitiveness and income of households.

According to the results of the Agriculture Census (2012), the total land of used agricultural land in the Republic of Serbia is 3.437.423ha. Family agricultural households account for $99.6 \%$ of the total. In the Republic of Serbia, there are 631.122 agricultural households, namely:

- 2.567 households of legal entities and entrepreneurs and

- 628.555 family agricultural households.

The share of primary agriculture in GDP of The Republic of Serbia between 2002 and 2012, ranged between 15.5\%-11.8\% (Gulan, 2014), which the best illustrates that agriculture is significant economic sector and deserves to be offered adequate support in terms of stimulating its development.

In the total value of agricultural development in 2013, plant production participated in $67.8 \%$, and livestock in 30.0\%, while most EU countries are reversed (Stevanovic et al., 2014). The dominant share of plant production is the indicator of underdevelopment of agriculture.

Agriculture potentials of Serbia are reflected in suitable conditions/resources (air, land, water), relatively qualified labor force, the existence of processing capacities, educational, scientific and research institutions, and agricultural advisors, nearness of EU market, agreement with Russian Federation, Belarus and Kazakhstan on duty/free exports, national treatment for foreign investors ${ }^{5}$.

On the other hand, small and fragmented properties, extensive production, poor representation of animal husbandry, inadequate solution of using state land, small areas under irrigation, poor organization of farmers, insufficient support for agriculture development by state are the real problems with which the agricultural sector is facing.

As special problem of Serbian agriculture, the share of raw land should be cited that amounts to about $12 \%$ of arable land (Census of Agriculture, 2012). Uncultivated land must be given to the use, in order to foster the process of enlargement of agricultural property, which presents the condition of development of modern farming and agriculture.

5 In the case of concession investments, the concession company is exempt from paying income tax for a period of 5 years from the date of agreed completion of the concession investment in whole. Exemption from paying income tax for large investments over a period of 10 years (investments over 8 million euros and hiring over 100 employers). Import of equipment based on foreign investment is exempt from customs and other.

EP 2017 (64) 2 (515-531) 
Possessory structure of land, as one of the negative characteristics of the agricultural structure in the Republic of Serbia can be depicted as follows:

Figure 1. Possessory Holding Structure in the Republic of Serbia

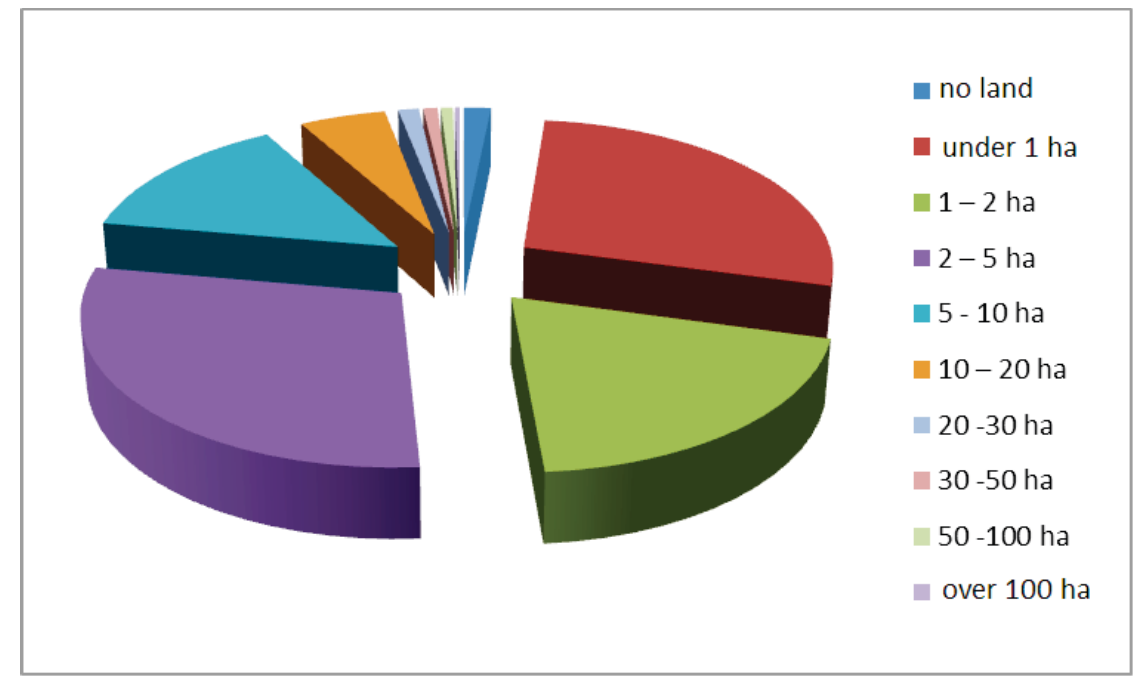

Source: Census of Agriculture in the Republic of Serbia (2012)

More than $3 / 4$ of households dispose with property, which is under 5 ha, while only $1 \%$ of households dispose with property over 50ha. Unfavorable agrarian (possessory) structure influenced and influences on the decline in productivity and competitiveness, from the various aspects.

Significance of agriculture can be observed through participation of employees in agriculture in total number of employees. Almost $1 / 4$ of employees are in agriculture, while Germany has much more competitive agricultural products and higher volume of agricultural production with only $2.4 \%$ of employee in agricultural sector. High participation of labor force indicates that it is about low-productive activities.

Agriculture would present the basis of the rapid development of total economy and significantly contribute to faster development of other economic activities by realization of the Strategy of agriculture development, food industry and versatile development of the countryside.

\section{Agricultural budget of the Republic of Serbia}

Due to specificity of agricultural activities (the length of the production cycle, slow capital turnover, low profitability, high risks and uncertainty), the adequate financial support is necessary to it. The role of state is based on providing the funds, which will put the agricultural households in more favorable economic position (Djuric et al., 2016). 
In the Republic of Serbia, set of laws is in preparation or in power, which aim is establishing instruments for financing the agriculture. From major significance are (Vasiljevic et al., 2015):

- Law on incentives in agriculture,

- Law on the financing and providing financing of agricultural production,

- Law on public warehouses for agricultural products and

- Draft law on commodity exchanges.

In preparing the country's budget, resources by purpose for agriculture, forestry and waterpower engineering, which is the component of the total budget, are determined (Babovic, Prodanovic, 2010).

Therefore, agricultural budget represents safe and permanent source of financing. Decision about forming the agricultural budget was adopted in late 1995, in order to intend first purpose resources in 1996. Agricultural budget is designed as conjoint source of state support to agriculture for maintenance the current production, and also providing development of this economic activity. Initial intention was to agricultural budget provides incentive resources for priority needs of agriculture, professional agricultural service, as well as the revitalization of the village.

The aims of agricultural budget are (Sindjic, 2007):

- Growth of production, productivity, exports and monitoring of technological innovation in agricultural production;

- Improving the quality of production and growth of agriculture competitiveness;

- Growth of living standards and ensuring adequate income in agriculture;

- Environmental protection and sustainability of production;

- Development of rural areas and stopping depopulation.

Stable practice is that developed countries help its agriculture by subsidies, premiums, tax breaks, affordable loans, but also provide cheap inputs. With the help of subsidies, developed countries provide enough food for their own needs, as well as for export. Therefore, it is wrong opinion that subsidies only help farmers, because the state has also benefit from them (Birovljev, Glamocanin, 2011).

Zivkov et al (2010), assert that agricultural policy of the Republic of Serbia is unpredictable and often susceptible to changing, even in one year, agricultural budget is insufficient for agriculture development, and there is a lack of subsidized loans for farmers (Vasiljevic et al., 2015).

One of the measures of agricultural policy are incentives, which include support for programs that are related to investments in agriculture for improving competitiveness and achieving standards of quality, and that are programs for support for investments in primary plant and livestock production (Official Gazette 105/14). Incentives in agriculture are aimed at stability 
in the supply of the domestic market with basic foodstuff, enhancing sales and exports, and job creation (Sacirovic, 2011).

In order to survive in conditions of excessive global supply of agricultural products, which is based on high direct and indirect protection, Republic of Serbia pursues active policy of incentives of domestic agricultural productions and export in accordance with conditions and terms of the world market, $\mathrm{WTO}^{6}$ and European Union, within the framework of CEFTA ${ }^{7}$ Agreement (Kuzman et al., 2013).

The purpose of incentives in agricultural production is the creating conditions for increasing its scope, increasing in employment and number of self-sustaining agricultural households, insurance of stable agricultural income and better living standard of farmers (Praća et al., 2017). The law defines sources and amount of funds, incentives models, users, conditions for achieving the incentives, financial incentive realization, reporting and storing documents, supervision over implementation, penal provisions, transitional and final provisions, as well as other issues (Masala, 2016). Incentives should encourage sustainability and profitability of the market-oriented farmers and advance technical-technological and organizational aspects (SBK Assembly, 2013).

Numerous researches claim that incentives can affect the production decisions and productivity of households. Subsidies can have positive influence on agricultural production and in some cases a negative impact on productivity in some households. Positive impact of subsidies in agriculture results from positive results of business, which is generated by subsidized investment. Negative impact of subsidies on productivity can be result of resources distribution (technical) and losses of efficiency due to distortion in structure of production and reallocation of inputs, soft budget restrictions and transition to subsidies for less productive enterprises. Subsidies can demotivate farmers to invest an effort in improving the business economics (Rizov et al., 2013).

Thus, in order to ensure stable production, food security, overcoming market difficulties, advancing some productions, stimulating the export, the state pursues policy of financial incentives (Babovic, Prodanovic, 2010).

According to the Rules on incentives for incentives support in primary plant production, incentives can be for:

- new machinery;

- irrigation equipment;

- material for the plant protection

- new implements and equipment for sowing, planting and harvesting;

- greenhouse and equipment;

- construction, expansion, reconstruction or adaptation of cold storage

6 World Trade Organization

7 Central European Free Trade Agreement 
- warehouses;

- the purchase of new equipment and machines for product preparation for the market.

Table 1. Amount of Incentives for Plant Production

\begin{tabular}{|l|c|c|}
\hline Items & $\begin{array}{c}\mathbf{2 0 1 5} \\
\text { Din/ha }\end{array}$ & $\begin{array}{c}\mathbf{2 0 1 6} \\
\text { Din/ha }\end{array}$ \\
\hline For plant production & 6000 & 2000 \\
\hline Regress for fuel and/or fertilizer & 6000 & 2.000 \\
\hline $\begin{array}{l}\text { Regress for insurance premium for crops, fruits, } \\
\text { perennial plants, nurseries garden and animals }\end{array}$ & $\begin{array}{c}40 \% \text { of paid insurance } \\
\text { premiums }\end{array}$ & $/$ \\
\hline Regress for storage costs & $40 \%$ of storage costs & $40 \%$ of storage costs \\
\hline
\end{tabular}

Source: Regulation on the allocation of subsidies in agriculture and rural development

In 2016, by regulation of the Government of Serbia on the allocation of subsidies in agriculture, basic incentives for plant production are decreased by 6.000 dinars to 2.000 dinars per hectare, and regress for purchase of inputs is decreased by 6.000 to 2.000 dinars per hectare, which additionally has perplexed problems that small farmers are faced with. Reduced incentives for plant production can be explained by interest of state to redirect funds to other items, such as livestock production. Limiting the land area at 20 ha, which can be supported by incentives, has led to fictitious splitting of larger households and that is one of the reasons of drastic reduction of the amount of incentives in plant production.

Subsidies are intended for the registered agricultural households that dispose of 1.2-1.4 million ha, which is a third of the total land area in the Republic of Serbia. For the rest of areas (over 2 million ha), subsidies are not contributed, and that are mostly farms in the south and southeast of the country, where the land is neglected, inaccessible, its price is low, and there is no interest in the lease (Bogdanov, Rodic, 2015).

Deadlines, when subsidies are paid to farmers, are not precisely defined and payments are delayed. Thus, household can not rely on these funds, than they are indebted in other way and subsidies are paid to them afterward, making it difficult to finance production (Radulovic, 2013). In such circumstances, it can not be spoken about comprehensive incentive system for improvement of agriculture, nor of its development.

Nikolic (2011) states that, in the period from 2003 to 2010, increase of financial support for agriculture from the republic budget of 100 million euros generated the increase of gross value added (GVA) of agriculture by 419 million euros. Coefficient of elasticity is 0.32 i.e. with $1 \%$ increase in agriculture subsidies GVA, increases by $0.32 \%$. 
Figure 2. Trend of the BDV of Agriculture and Agricultural Subsidies (in Millions of Euros)

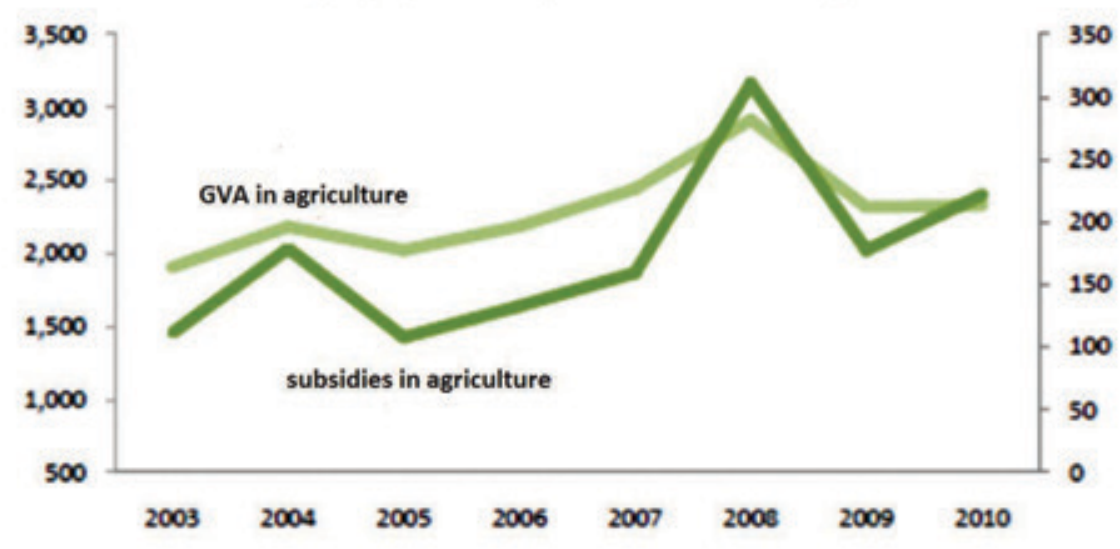

Source: Nikolic (2011)

In addition, according to the Regulations, incentives for livestock production are given for:

- the purchase of new equipment for improving the efficiency of livestock production and preparation of forage;

- the purchase of new equipment for milking cow accommodation, beef cattle, sheep, goats and poultry;

- the purchase of new equipment for manipulation, disposal, separation and distribution of solid and liquid manure;

- the purchase of new equipment that protects animal welfare;

- the purchase of quality breeding throat;

- the purchase of new equipment for fishponds and beekeeping production;

- the purchase of objects and equipment for the storage of meat.

Table 2. Amount of Incentives in Livestock (minimum amount)

\begin{tabular}{|l|c|c|}
\hline \multirow{2}{*}{ Types of livestock } & \multicolumn{2}{|c|}{$\begin{array}{c}\text { The minimum amount / head } \\
\text { (Dinars) }\end{array}$} \\
\cline { 2 - 3 } & $\mathbf{2 0 1 5}$ & $\mathbf{2 0 1 6}$ \\
\hline Breeding dairy cows/ beef cows & 25.000 & 25.000 \\
\hline Dairy cows & 20.000 & 20.000 \\
\hline The premium for milk & $7 \mathrm{din} / 1$ & $7 \mathrm{din} / 1$ \\
\hline Breeding sheep and goats & 7.000 & 7.000 \\
\hline Breeding sows & 7.000 & 7.000 \\
\hline Fattening cattle & 10.000 & 10.000 \\
\hline Fattening lambs and kids & 2.000 & 2.000 \\
\hline Fattening pigs & 1.000 & 1.000 \\
\hline
\end{tabular}




\begin{tabular}{|l|c|c|}
\hline \multirow{2}{*}{ Types of livestock } & \multicolumn{2}{|c|}{$\begin{array}{c}\text { The minimum amount / head } \\
\text { (Dinars) }\end{array}$} \\
\cline { 2 - 3 } & $\mathbf{2 0 1 5}$ & $\mathbf{2 0 1 6}$ \\
\hline Beehives & 500 & 600 \\
\hline Parental chickens heavy type & 60 & 60 \\
\hline Parental chickens light type & 100 & 100 \\
\hline Parental turkeys & 300 & 300 \\
\hline Breeding parent fish carp & 500 & 500 \\
\hline Breeding parent fish trout & 300 & 300 \\
\hline Consumable fish & $10 \mathrm{din} / \mathrm{kg}$ & $10 \mathrm{din} / \mathrm{kg}$ \\
\hline
\end{tabular}

Source: Regulation on the Allocation in Agriculture and Rural Development

Encouraging the production of high-quality breeding animals, respectively, proper selection increases the production. The intention should be on motivation of farmers to invest in expanding capacity and improving the quality of products, which will create conditions for stable income of agricultural households, maintain continuity of production and advance it.

Incentives are determined mainly in \% of the realized investment value, and the highest total amount of incentive for livestock production is 3.000.000 dinars per applicant, except for facilities for the meat storage for which the highest amount of incentives is 6.000.000 dinars (Official Gazette, 38/16).

Payments per product, as the case of premium for delivered milk, are unacceptable in the EU model of $\mathrm{CAP}^{8}$ thus, it must be timely reformed (Mitrovic, 2015). ZAP realizes incentives in livestock production per head of cattle, not in volume of production. Therefore, premium for milk must be abolished in process of agricultural policy harmonization with the EU ZAP.

The state has increased the support for investments in agriculture. In 2016, households, to a maximum of 50 ha of declared area under plants, for which the equipment and machinery are planned to use, could obtain the grants for docking machinery and equipment. Subsidizing the price of new equipment for preparation and distribution of forage amounts to $40-55 \%$ of price excluding VAT, respectively, $55 \%$ if the user of incentive is in marginal area or if it is about difficult working conditions. Amount for each item on the bill must be over 50.000 dinars, provided that the applicant has not already received the investment on the same basis (confirmation from the municipality) (www.subvencije.rs).

Incentives in agriculture of the Republic of Serbia are quite modest in comparison to the incentives, which are given by EU to its farmers. Thus, for instance, European agricultural producers obtain on average of 368 euros per hectare of arable land (Zivanovic, Milovanovic, 2011), while Serbian farmers can rely on 35 euros/ha. Relatively modest financial incentives did not contribute to stronger development of agriculture (Agricultural and Rural Development Strategy of the Republic of Serbia, 2013).

8 Common Agricultural Policy

EP 2017 (64) 2 (515-531) 
Incentives in agriculture and rural development should support underdeveloped sectors of agricultural production, through stimulating the increase in quantity and quality, in order to advance competitiveness and to achieve higher economic and environmental effects. In such context, Republic of Serbia creates and conducts agricultural policy measures, gradually adapting to EU principles ZAP (Milovanovic, 2011).

Agricultural policy, which will stimulate the change of crop production structure, respecting, support for investing in more intensive production (truck farming, fruit growing, viticulture), as well as increasing the total livestock, is necessary, in order to get greater effects by agriculture.

The biggest challenge for agriculture of the Republic of Serbia is the increase of competitiveness, finding new markets, adapting to new EU and WTO standards, adopting new knowledge and technologies. By entrance in new markets, as well as the acceptance of foreign products, it is reasonable to expect a change of the production structure in favor of more intensive and export-oriented production (Bozovic, Bozovic, 2011).

Quantitative aspect of agricultural budget of the Republic of Serbia, in the period from 2008 to 2017, is presented in Table 3. In the reporting period, the average share of agricultural budget in total state budget was below 5\%, although it is determined by the Law on Incentives in Agriculture and Rural Development that it can not be less than 5\% of the budget of the Republic of Serbia, starting from 2014 (Radovic, 2015).

Table 3. The Share of Agricultural Budget in the Budget of the Republic of Serbia (20082017)

\begin{tabular}{|c|c|c|c|}
\hline Year & $\begin{array}{c}\text { Budget of the Republic } \\
\text { of Serbia (in mil. of din) }\end{array}$ & $\begin{array}{c}\text { Agricultural budget of the } \\
\text { Republic of Serbia } \\
\text { (in mil. of din) }\end{array}$ & $\begin{array}{c}\text { The share of } \\
\text { agricultural in total } \\
\text { budget (\%) }\end{array}$ \\
\hline 2008 & $695.959,10$ & $32.895,40$ & 4,70 \\
\hline 2009 & $719.854,10$ & $26.690,40$ & 3,70 \\
\hline 2010 & $825.884,90$ & $31.577,90$ & 3,80 \\
\hline 2011 & $824.575,90$ & $33.676,00$ & 4,10 \\
\hline 2012 & $1.018 .633,40$ & $40.876,70$ & 4,00 \\
\hline 2013 & $1.040 .014,30$ & $44.699,50$ & 4,30 \\
\hline 2014 & $1.110 .121,00$ & $45.427,20$ & 4,10 \\
\hline 2015 & $1.082 .988,20$ & $45.308,20$ & 4,20 \\
\hline 2016 & $1,119.000,00$ & $40.600,00$ & 3,60 \\
\hline 2017 & $1.162 .000,00$ & $43.778,00$ & 3,80 \\
\hline $\begin{array}{l}\text { AVERAGE }- \\
\text { THE SHARE }\end{array}$ & & & $\mathbf{4 , 0 3}$ \\
\hline
\end{tabular}

Source: Ministry of Agriculture of the Republic of Serbia

The amount of agricultural budget funds is determined due to numerous factors as: economic opportunities in country, the necessity to pay other budget consumers, and surely, it can not be said that it was a reflection of the real needs of farmers and rural developments 
(Agricultural and Rural Development Strategy of the Republic Serbia, 2013).

The trend of reduction of agricultural budget adversely is reflected in agricultural sector's development, both the structure and amount of funds. General assessment is that the country does not allocate serious resources from state budget for agriculture.

Urgent need is imposed to redefine the structure of state budget, where the allocation for agriculture will make significantly bigger part. Some agricultural economists believe that participation in the total budget should be minimum of $12 \%$ (Lekic, 2011).

\section{The Structure of Agricultural Budget}

The structure of agricultural budget should reflect agricultural policy measures, which are conducted by the European Union, where about $20 \%$ of agricultural budget is directed to rural development, i.e. development of non-agricultural activities, which can, such as rural tourism, initiate diversification and rural economy development (www.poljoprivrednik. net - 01 September 2016).

Since the Republic of Serbia anticipates upcoming process of European integration, as well as big necessity of the agricultural sector for adequate support, significant change in agricultural budget structure is inevitable. Review of state aid policy to agriculture should be in direction of greater allocation of resources for livestock production and underrepresented sectors of plant production, but also rural development, through not only investment measures, but measures which are aimed to improve living standards in the village (Vojinovic et al., 2017).

Agricultural budget is devoted to subsidizing of agricultural production through: (Milovanovic, 2011):

- Incentives or direct payments provide conditions for market orientation of producers and enhancing the competitiveness.

- Market support includes activities, which contribute to market stabilization, advancement, promotion and placement of product. Vasiljevic et al. (2015) assert that implementation of intervention in the market contributes to reduction risk of business in agricultural sector, as well as creating possibilities for establishment of trades future to agricultural products.

- Structure support for modernization and development of agricultural-food sector, conducts through investments (incentives for strengthening competitiveness, protection of biodiversity and diversification of the rural economy);

- Institutional support provides stable functioning of institutions in the field of agriculture (cooperative, funds, professional advisory services, education, etc.)

In 2016, resources of agricultural budget are allocated to: direct payments, support for rural development, credit support and special incentives (Djuric et al., 2016). 
Table 4. Structure of Agricultural Budget in 2016

\begin{tabular}{|l|c|}
\hline \multicolumn{1}{|c|}{ Type of support } & Participation in agricultural budget (u \%) \\
\hline Direct payments & 87 \\
\hline Rural development measures & 9 \\
\hline Credit support & 3 \\
\hline Special incentives & 1 \\
\hline IN TOTAL & $\mathbf{1 0 0}$ \\
\hline
\end{tabular}

Source: Djuric et al., 2016.

In 2016, the most resources are allocated for direct payments- 87\%, support for rural development- only $9 \%$, and the rest on credit and special incentives.

Direct payments per ha (dominant item of agricultural budget) is measure, which does not influence supportive on advancement of product quality. That is one of the reason for reducing the support for plant production in 2016 (Bogadnov, Rodic, 2015). Since 2005, Republic of Serbia negotiates with World Trade Organization (WTO) for accession, and thus, it is obliged to abolish direct subsidies for agricultural production (Vasiljevic et al., 2015).

Support measures for rural development are minimally represented in agricultural budget, and with it, the amount of financial resources for their realization is decreasing in recent years, which is the essential opposite to support for rural development concept in the EU. The biggest part of agricultural budget is spent on direct payments, while investments, growth of competitiveness, environmental issues, as well as support for rural development are completely ignored (Bogdanov, Rodic, 2015).

Special incentives are aimed to conduct the breeding program selection, as well as incentive to scientific research and innovation projects, for which very little funds in the budget is allocated (Djuric et al., 2016). It is clear that without support for science and education, there are no serious results in agriculture development because modern agriculture is exclusively based on knowledge.

In the item of direct payments, the most money is allocated to premium for milk (20.02\%), basic incentives for plant production (20.78\%), incentives for high/quality breeding animals and breeding fish nuts (30.98\%), and regress for fertilizer $(20.78 \%)$.

Table 5. Structure of Direct Payments (2016)

\begin{tabular}{|l|c|}
\hline \multicolumn{1}{|c|}{ Type of Incentive } & The share (\%) \\
\hline Premiums for milk & 20.02 \\
\hline Basic incentives for plant production & 20.78 \\
\hline $\begin{array}{l}\text { Incentives for quality breeding dairy cows, beef cattle, sheep and goats, } \\
\text { sows, parental chickens light and heavy type, parental turkeys, quality } \\
\text { breeding parent carp fish and trout }\end{array}$ & 30.98 \\
\hline Incentives for fattening cattle, lambs, kids, pigs & 5.30 \\
\hline Incentives for suckler cow & 0.12 \\
\hline Incentives for bees & 1.89 \\
\hline
\end{tabular}




\begin{tabular}{|l|c|}
\hline Incentives for consumption fish production & 0.17 \\
\hline Regress for fertilizer & 20.78 \\
\hline Regress for storage costs & 0.01 \\
\hline TOTAL & $\mathbf{1 0 0 . 0 0}$ \\
\hline
\end{tabular}

Source: Djuric et al., 2016

In 2016, support for rural development from agricultural budget includes investments for enhancing the competitiveness and achieving the quality standards (65\%), support for advisory professional services (19\%), while resources devoted to sustainable agriculture development and rural economy are symbolic (10\%). Consistent implementation of integral rural development concept requires significantly bigger resources, especially for infrastructure development, without which there are no establishing modern villages or agricultural development.

Table 6. Support Structure for Rural Development (2016)

\begin{tabular}{|l|c|}
\hline \multicolumn{1}{|c|}{ Type of subsidy } & The share (\%) \\
\hline $\begin{array}{l}\text { Investments in agricultural production for improvement of competitiveness } \\
\text { and achieving quality standards }\end{array}$ & 65 \\
\hline Incentives for sustainable rural development & 8 \\
\hline Incentives for improving the rural economy & 2 \\
\hline Incentives to support for advisory and professional jobs in agriculture & 19 \\
\hline Participation funds in the financing of IPARD measures & 3 \\
\hline TOTAL & $\mathbf{1 0 0}$ \\
\hline
\end{tabular}

Source: Djuric et al., 2016

Agricultural budget should support those productions that are not developed, and for which there are real conditions and resources, as well as livestock production. Direct payments have their excuse, but agriculture development is provided by new investments in knowledge, equipment and new technologies. Support for young farmers, introduction of quality standard and environmental protection is needed.

\section{Conclusion}

Funds of agricultural budget are not sufficient for more dynamic agriculture development. Development of agriculture requires increasing the agricultural budget and allocation of resources to investments and rural development programs. The share of agricultural budget should gradually get close to \% of agriculture share in GDP, respectively, the share of $10 \%$ in national budget. Priority aim of agricultural policy of the Republic of Serbia should be measures of support for development of intensive plant productions, development of livestock production, relatively, rural development and export orientation of quality highfinalized agricultural products.

It is necessary to establish domestic agricultural institutions in order to implement the model of support for agriculture, which is applied by the European Union, with certain adaptations in accordance with specifics of the Republic of Serbia. 
Subsidies in agriculture should be focused on enhancing the yield, without ignoring the agricultural products' quality. In this context, rational use of natural resources through the system of organic production can ensure better positioning, especially in foreign markets, preservation of producing possibilities in the long term.

For agricultural development, it is necessary to implement adopted Agricultural and rural development strategy consistently, provide external financing, increase agricultural budget, subsidized production, investments and loans (interest rate) and establish advisory services, which task will be overview of local farmers' needs and solving their problems.

Economic empowerment of agricultural households should be the guiding principle in the design and implementation of agricultural policy measures (agricultural budget), because only economic strong household can provide agriculture development.

\section{Literature}

1. Babović, J., Prodanović, R. (2010): Menadžment u agrobiznisu-praktikum, Fakultet za ekonomiju i inženjerski menadžment, Novi Sad.

2. Birovljev, J., Glamočanin, B. (2011): Poljoprivreda Srbije i materijalno finansijski podsticaji u odnosu na kretanja u Evropskoj uniji, pp. 25-38, u: Tematski zbornik: Agrarna i ruralna politika u Srbiji nužnost ubrzanja reformi, urednici: Tomić, D., Ševarlić, M., Zekić, S. DAES - Društvo agrarnih ekonomista Srbije - Univerzitet u Novom Sadu Ekonomski fakultet.

3. Bogdanov, N., Rodić, V. (2015): Poljoprivreda i poljoprivredna politika u Srbiji, u tematskom zborniku: Poljoprivredna politika i evropske integracije u jugoistočnoj Evropi. Urednici: Volk, T., Erjavec, E., Mortensen, K. pp. 177-196, Organizacija Ujedinjenih nacija za hranu i poljoprivredu - FAO.

4. Božović, I., Božović, J. (2011): Izazovi finansiranja agrobiznisa u Srbiji. AGROBIZ 2011", International University of Novi Pazar.

5. Đurić, K., Vukoje, V., Tomaš - Simin, M. (2016): Agrarni budžet kao oblik finansiranja poljoprivrede u Republici Srbiji i Hrvatskoj. Agroekonomika, Vol. 45, No. 71, pp. 13-21.

6. Finansijska podrška preko specijalizovane poljoprivredne banke. (available at: http:// www.poljoprivrednik.net/izdvajamo/768-finansijska-podrska-preko-specijalizovanepoljoprivredne-banke), accessed at: 01.09.2016.

7. Gulan, B. (2014): Stanje i perspektive poljoprivrede i sela u Srbiji, Privredna komora Srbije, Beograd.

8. Kuzman, B., Tešić, A., Đelić-Tanja, A. (2013): Possible Routes OfApproaching Of Serbia (AgroIndustrial Complex) To The Eu And The Wto, Economics of Agriculture, Vol. 60, No. 3, pp. 541-549.

9. Lekić, V. (2011): Predlog neophodnih subvencija za izvoz prehrambenih proizvoda, iz ugla proizvođača prehrambenih proizvoda. Poljoprivredni forum - Hrana za evropu, Agroprivreda Srbije u predpristupnom periodu, Subotica, 13 -15. oktobar 2011.

10. Mašala, M. (2016): Program utroška sredstava Ministarstva za privredu sa ekonomskog 
koda 614 500. Bosansko-podrinjski kanton Goražde, Federacija Bosne i Hercegovine, $\mathrm{BiH}$.

11. Milovanović, M. (2011): Finansijske prepreke i podsticaji razvoju agroprivrede Srbije u predpristupnom periodu, Poljoprivredni forum - Hrana za evropu, Agroprivreda Srbije u predpristupnom periodu. Subotica, 13-15. October 2011.

12. Mitrović, F. (2015): Analiza efekata i mogućnosti unapređenja primene subvencija kao mehanizma za podsticanje LER-a, Stalna konferencija gradova i opština - Savez gradova i opština Srbije, Beograd.

13. Nikolić, I. (2011): Analiza subvencija i drugih budžetskih podsticaja, Poljoprivredni forum - Hrana za evropu, Agroprivreda Srbije u predpristupnom periodu. Subotica, 13 -15 . October 2011.

14. Popis poljoprivrede 2012 (2013): Poljoprivreda u Republici Srbiji - Knjiga I i II. Republički zavod za statistiku, Beograd, Srbija.

15.Praća, N., Paspalj, M., Paspalj, D. (2017): Ekonomska analiza uticaja savremene poljoprivrede na održivi razvoj, Oditor, Vol. 3, No. 1, pp. 37-51.

16. Pravilnik o podsticajima za podršku investicijama u primarnu poljoprivrednu proizvodnju „Official Gazette of RS, no. 105/14 from 3. October 2014.

17. Pravilnik o podsticajima za investicije u poljoprivredi za unapređenje konkurentnosti dostizanje standarda kvaliteta kroz podršku u primarnu proizvodnju biljnih kultura (Official Gazette no. 38/16).

18. Pravilnik o podsticajima za investicije u poljoprivredi za unapređenje konkurentnosti dostizanje standarda kvaliteta kroz podršku u primarnu stočarsku proizvodnju (Official Gazette no. 38/16).

19. Radović, G. (2015): Finansiranje poljoprivrede u RepubliciSrbiji: iskustva i mogućnosti, Ekonomija teorija i praksa, Vol. 8, No. 4, pp. 13-27.

20. Radović., G. (2009):Podrška države ufunkcijifinansiranjapoljoprivrede, Agroekonomika, No. 41-42, pp. $69-79$.

21. Radulović, Đ. (2013): Poljoprivredno gazdinstvo u procesu obezbeđivanja izvora finansiranja, III Poljoprivredni forum - Hrana za evropu, Investirajmo u agroprivredu Srbije. Subotica, 17 -19. October 2013.

22. Rizov, M., Pokrivcak, J. and Ciaian, P. (2013): CAP Subsidies and the Productivity of EU Farms. Comparative Analysis of Factor Markets for Agriculture across the Member States, Centre for European Policy Studies (CEPS), Brussels.

23. Sinđić, V. (2007): Dinar za razvoj, poslovanje, konkurentnost, magazin 'Poljoprivreda".

24. Skupština Srednjebosanskog kantona (SBK) (2013): Zakon o novčanim podsticajima u poljoprivredi na području Srednjobosanskog kantona, Travnik.

25. Stevović, M., Lalić, I., Karamarković, S., Milojić, A., (2014): Ekonomski računi poljoprivrede u Republici Srbiji 2007-2013. Republički zavod za statistiku no. 81, Belgrade. 
26. Strategija poljoprivrede i ruralnog razvoja Republike Srbije (2014-2024) (2013): Ministarstvo poljoprivrede, šumarstva i vodoprivrede Republike Srbije (MPŠV).

27. Šaćirović, M. (2011): Podsticaji u razvoju agrobiznisa. AGROBIZ 2011” International University of Noekonomika poljoprivredevi Pazar.

28. Uredba o raspodeli podsticaja u poljoprivredi i ruralnom razvoju u 2015. godini, Official Gazette of RS, no. 19/15 from 20. February 2015.

29. Uredba o raspodeli podsticaja u poljoprivredi i ruralnom razvoju u 2016. godini, Official gazette of the RS no. 8/16 from 01. February 2016.

30. Vasiljević, Z., Zakić, V., Kovačević, V. (2015): Najnovija zakonska regulativa u Republici Srbiji u oblasti podsticaja i finansiranja poljoprivrede i ruralnog razvoja, Agroznanje, Vol. 16, No. 1, pp. 33-45.

31. Vojinović, Ž., Zelenović, V., Cvijanović, D. (2017): Program Of State Support To Agricultural Crediting, Economics of Agriculture, Vol. 64, No. 1, pp. 339-358.

32.Živadinović, B., Milovanović, M. (2011): Vodič kroz EU politike - Poljoprivreda. Evropski pokret u Srbiji, Beograd. 


\title{
AGRARNI BUDŽET I RAZVOJ POLJOPRIVREDE U REPUBLICI SRBIJI
}

\author{
Boris Kuzman ${ }^{9}$, Katarina Đurićc ${ }^{10}$, Ljubomir Mitrović ${ }^{11}$, Radivoj Prodanović ${ }^{12}$
}

\section{Rezime}

S obzirom da je poljoprivreda značajna privredna delatnost u Republici Srbiji, država vodi politiku njenog podsticanja kroz agrarni budžet, kako bi se razvijala i donosila još veće efekte. Cilj rada je da se prikaže stanje poljoprivrede u Republici Srbiji i agrarni budžet, kao instrument agrarne politike u funkciji razvoja poljoprivrednog sektora. Nastoji se istražiti da li je visina i struktura agrarnog budžeta adekvatna ciljevima Strategije razvoja poljoprivrede Republike Srbije. Primenom istorijskog i deskriptivnog metoda sagledan je uticaj agrarnog budžeta na razvoj poljoprivrede u Republici Srbiji. Sa druge strane, komparativna analiza statističkih podataka obezbedila je donošenje zaključaka o strukturi $i$ veličini agrarnog budžeta za budući period. Koristi se i grafički metod, indikatori, logički metod i drugi standardni metodi. Za dinamičniji razvoj poljoprivrede Republike Srbije, sredstva agrarnog budžeta nisu dovoljna. Neophodna je reforma agrarne politike, gde će agrarni budžet dobiti na značaju. Najefektnije je sredstva usmeriti na nove investicije, infrastrukturne projekte u ruralnim područjima, podsticati intenzivne i izvozno orijentisane proizvodnje, preradu, kao $i$ sisteme održive poljoprivrede.

Ključne reči: agrarni budžet, agrarna politika, poljoprivreda, ruralni razvoj, Republika Srbija

9 Vanredni profesor, Boris Kuzman, Institut za ekonomiku poljoprivrede, Volgina 15, 11060 Beograd, Srbija, Telefon: +381 63299 111, E-mail: kuzmanboris@yahoo.com

10 Vanredni profesor, Katarina Đurić, Poljoprivredni fakultet, Trg Dositeja Obradovića 8, 21000 Novi Sad, + 381214853 232, E-mail: katarina.djuric@polj.uns.ac.rs

11 Redovni profesor, dr Ljubomir Mitrović, Univerzitet u Prištini, Pravni fakultet, Kosovska Mitrovica,Telefon: +38128425 339, E-mail: slavka.mitrovic@pr.ac.rs

12 Docent, dr Radivoj Prodanović, Univerzitet Privredna akademija u Novom Sadu, Fakultet za ekonomiju i inženjerski menadžment u Novom Sadu, Cvećarska 2, 21000 Novi Sad, Srbija, Telefon: +381 21400 484, E-mail: rprodanovic@fimek.edu.rs

EP 2017 (64) 2 (515-531) 